\title{
CORRESPONDENCE
}

\section{Toxicity testing}

SIR - The dramatic fall in Fisons' shares as a result of the withdrawal of Proxicromil emphasizes the high risks involved in drug development (Nature 12 March, p.81). Drug development programmes depend on animal tests for assessing long and short term toxic effects which are notoriously unreliable and expensive.

The effects of drugs on animals cannot be assumed to be the same in humans, irrespective of whether results indicate that a drug is "safe" or "harmful". Legislators should accept this fact and release toxicologists from the present "check-list" testing system which has replaced scientific initiative with standard tests of dubious relevance which are carried out on ever increasing numbers of animals.

On scientific, economic and humanitarian grounds current toxicity testing protocols should be refined to ensure the most efficient use of animals and to incorporate valid nonanimal screening tests wherever possible.

LesLey SaRGEANT

Fund for the Replacement of Animals in Medical Experiments,

London, UK

\section{Inherited tolerance?}

\section{SIR - I would like to suggest a more} straightforward explanation of the fascinating findings of Gorczynski and Steele ${ }^{1}$ than the one they have opted for. There is a strong possibility that mouse semen contains some cells other than sperm - lymphocytes, for example. In the mouse, semen is ejaculated intra-cervically, rather than intra-vaginally as in humans. Thus any non-sperm cells will be directly introduced into the uterus in the mouse. Not much is known about the fate of such cells although it appears that sperm are rapidly removed by phagocytosis. The pregnant uterus, however, is to some extent tolerant of foreign cells. Short and Yoshinaga ${ }^{-2}$, Wilson ${ }^{3}$ and Lions ${ }^{4}$ have described experiments which show that heterologous tumour cells can persist for several days in the rat uterus and that these can enter the mucosa only at the time of implantation in pregnancy. Thus the endometrium becomes receptive to foreign cells at the time of implantation, and so nonsperm cells present in semen could presumably become established in the endometrium and might then enter the embryo after implantation.

If we then suppose that tolerance involves clones of cells in a manner analogous to immunity and that some of the non-sperm cells are competent for the transmission of the tolerant state, the embryo might be rendered tolerant to the same antigens as the father. Moreover, if the chances of such an invasion of the embryo were less than 100 per cent. tolerance of a particular antigen would be found in only a proportion of the embryos and some would be tolerant to both of two antigens whilst others would be tolerant only to one. Since the postulated cells conferring tolerance are differentiated they would play no part in embryogenesis but would be carried and perhaps multiplied in the embryo. In subsequent generations, the chances of transmission of the cells would be finite and the incidence of tolerance to specific antigens would decline. In the mothers, the return to the non-pregnant state after parturition would, presumably, involve the rejection of any foreign clones of cells in her tissues. Thus, subsequent matings to non-"tolerized" fathers would not result in the transmission of previous tolerant states.

In this way, the essential aspects of the Gorczynski and Steele experiments might be explained along rather less controversial lines than at present. At the very least, the possibilities raised here must be eliminated before we venture to compromise the doctrine of Weismann and begin resurrecting the long dead Lamarck.

Department of Genetics,

K.W. JONES

University of Edinburgh,

Edinburgh, UK

I. Gorczynski, R.M. \& Steele, E.J. Nature 289, 678-68 (1981)

2. Short, R.V. \& Yoshinaga, K. J. Reprod. Fert. 14, 287 (1967)

. Wilson, I. B. Proc. zool. Soc. Lond. 141, 137 (1963).

4. Lions, J. thesis, Univ. Cambridge (1970)

5. I thank Johnathan Aitken for discussion of these ideas and for the references cited.

\section{Exhibit dismay}

SIR - I have been following with great interest and some dismay the extended correspondence in Nature about the nature and significance of new exhibits in the British Museum (Natural History). I wish to comment on recent letters from three colleagues and fellow-countrymen of mine ${ }^{1-3}$, one British colleague $\mathrm{e}^{4}$ and one French colleague ${ }^{5}$

McKenna ${ }^{1}$ and Nelson ${ }^{2}$ speak out against Halstead and in favour of cladistic or Hennigian systematics, to which a considerable part of the new dinosaur exhibit is devoted. Both McKenna and Nelson are now at the American Museum of Natural History, with which I was associated for many years. They belong to a small group now there which is representative neither of the staff of the museum as a whole nor of the majority of American palaeontologists, who, like me, reject Hennigian procedures.

Gould $^{3}$ is at the Museum of Comparative Zoology, with which I was also associated for some time. He proclaims that he is not a cladist and "did not care for" the cladistic exhibits at Cromwell Road. He also claims that his theory of punctuated equilibrium is not a Marxist plot and notes that the coauthor of the theory, Eldredge, is not a Marxist. I do not wish to discuss Marxism in this connection, but I do note that the punctuated equilibrium of Eldredge and Gould is only one facet, taken to an extreme, long since incorporated in the synthetic or if you like, neo-Darwinian, theory of evolution.

Howgate ${ }^{4}$ named me as being "by no means averse to the idea of leaps," that is, to saltatory evolution. He quotes as evidence a statement by me in a book published in 1949 (not 1976 as he has it) that rates of evolution in the horse family varied considerably. I did not state or imply that the rates were ever saltatory, that is, instantaneous.

Janvier, of the Laboratoire de

Paléontologie des Vertebrés of the University of Paris claims that cladism is "directly descended from Darwin's ideas on phylogeny and systematics." In context this implies that Darwin was a saltationist, which is not true.
He also notes that some French scientists (Grassé as an example) are anti-Darwinian. In fact French biologists, with the exception of a few radicals, have always been anti-

Darwinian, at times for no clear reason other than chauvinism.

Department of Geosciences,

G.G. SIMPSON

University of Arizona, Tucson, USA

1. McKenna, M.C. Nature 289, 626 (1981).

2. Nelson, G. Nature 289, 627 (1981).

3. Gould, S.J. Nature 289, 742 (1981).

4. Howgate, M. Nature 289, 344 (1981)

5. Janvier, P. Nature 289, 626 (1981).

\section{Evolving theory}

SIR - The letter from H.W. Ball and 21 colleagues (Nature 12 March, p.82) contains the following astounding statement: "But the theory of evolution would be abandoned tomorrow if a better theory appeared".

The lapse of time between the appearance of a "better theory" and the abandonment of its predecessor can be established with fair accuracy in many topics of science. The history of science provides a large number of such events. Accordingly, the lapse of time between the appearance of the new and the relinquishing of the old might be regarded as one of the many facts of science. Your 22 correspondents, apparently seriously, estimate the magnitude of this lapse of time as one day. One day! They declare their devotion to fact and their abhorrence of prejudice. Are their other facts of a similar colour I wonder, or does evolution evolve more rapidly than any other field of science?

Berkeley Nuclear Laboratories, R.V. HESKETH Berkeley, Glos., UK

SIR - Bertolt Brecht put these words into the mouth of Galileo' :

"And what we discover today we shall wipe off the slate tomorrow and only write it up again once we have again discovered it. And whatever we wish to find we shall regard, once found, with particular mistrust. So we shall approach the observation of the sun with an irrevocable determination to establish that the earth does not move. Only when we have failed, have been utterly and hopelessly beaten and are licking our wounds in the profoundest depression, shall we start to ask if we weren't right after all, and the earth does go round."

As far as evolution is concerned, I think most biologists would agree that "the earth does go round", there being no better way of accounting for the facts at present. So how are we to understand the over-cautious round robin from the British Museum? There is a world of difference between "If the theory of evolution is correct . ..", and ". . . evolution is a fact, proven to the limits of scientific rigour." Most of us, like yourself, would wish to be more positive than the first but less dogmatic than the second. In these days of proliferating crazies, the British Museum should not risk giving them more ammunition.

Queen's College, Oxford, UK P.L. MiLLER

1. Brechi, B. Life of Galileo (transiated by J. Willett) (eds Willett, J. \& Manheim, R.) (The Collected Plays Vol.5 pt 1, Eyre Methuen, London, 1980). 